\title{
Transforming the health landscape in northern communities: Shared leadership for innovation in nursing education
}

\author{
Lois Berry, Lorna Butler, Amy Wright \\ College of Nursing, University of Saskatchewan, Saskatoon, Canada. \\ Correspondence: Amy Wright. Address: College of Nursing, University of Saskatchewan, Saskatoon, Canada. \\ Email: wrightam@hhsc.ca.
}

Received: May 5, 2014

Accepted: June 10, $2014 \quad$ Online Published: June 25, 2014

DOI : $10.5430 /$ jnep.v4n9p33

URL: http://dx.doi.org/10.5430/jnep.v4n9p33

\begin{abstract}
People living in northern areas throughout the world experience poorer health status than their southern neighbours. Accessibility to health care services and availability of health care professionals play a role in the building of health capacity in northern regions. The College of Nursing at the University of Saskatchewan developed a principled approach to the creation of an indigenous nursing workforce in Northern Saskatchewan. This approach builds on Williams' concept of Therapeutic Landscapes, which recognizes the connectedness among environment, social interaction, and symbolic meaning within a population, and offers a way to analyze the influence of the contextual factors of place on health, and values and attitudes on well-being. In order to succeed, the College developed mutually beneficial, capacity-building relationships with northern communities, finding local champions to assist them. They reorganized their administrative structure to give visibility to their northern relationships, and built a distributive learning approach based on the commitment to "learn where you live". Measuring the success of such approaches requires the development of new and innovative evaluation strategies, beyond the usual markers of individual student success. It requires approaches that capture the impact of such education programming on the fabric of the community as a whole.
\end{abstract}

\section{Key words}

Northern education, Nursing, Capacity building, Therapeutic landscapes

\section{Introduction}

This paper outlines the mutually beneficial, capacity building approaches taken by the College of Nursing at the University of Saskatchewan to develop and implement a nursing education program in Northern Saskatchewan, Canada, aimed at building a local Indigenous health professional workforce to address northern health disparities. The provision of health services to the region, the health status of Northern Saskatchewan residents, and the availability of Indigenous health professionals in the Saskatchewan north relative to the global context will all be described. Ultimately, a principled approach to educational programming in the north is proposed, building on concepts based in the geographies of health.

\subsection{What is "North"?}

Before embarking on a further discussion of Northern Saskatchewan, we must first define "north". While some authors take an arbitrary approach to defining "north-ness" based on a dividing line at 60 degrees of latitude, such a definition does 
not satisfy the discussion of Northern Saskatchewan. While north is clearly a geographic location as well as a direction, north is a relative term. In order to define Northern Saskatchewan, the authors relied on the historic work of Hamelin ${ }^{[1]}$, who developed a complex algorithm to categorize northern-ness, based on indicators including latitude, temperature, topography, settlement patterns, economic activity, forestation, annual growing period, presence of permafrost, population density, road and rail accessibility, air accessibility, accessibility to services, living costs in relation to accessibility, and degree of economic activity. This work is still relied upon by Statistics Canada to inform its definition of north. This work has been further developed and elaborated on by the authors for the purpose of this paper in Table 1.

Table 1. "North"

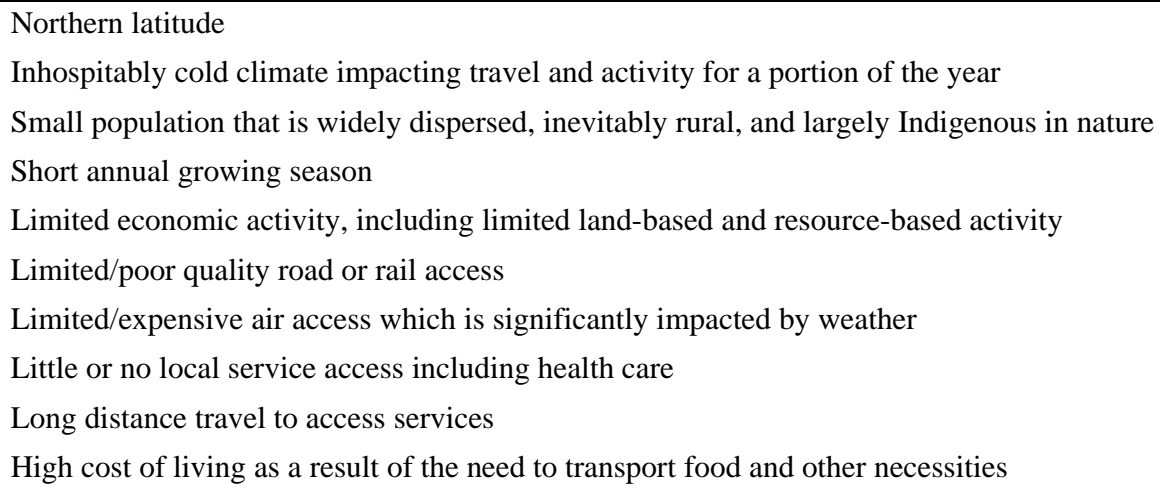

As shown in Table 1, a geographical area with most or all of these conditions Northern Saskatchewan is defined in this paper as the part of Saskatchewan in the Northern Administrative District (NAD) as defined by the Government of Saskatchewan. The NAD is a geographic area in Saskatchewan defined in complex and detailed legislation and determined by geography, road access, population distribution and service availability. It includes almost half of Saskatchewan's land mass, almost 270,000 square kilometers, and parts of Treaties 6,8 and $10^{[2,3]}$.

\subsection{Health and health services across the North}

Having satisfied our definition of what is "north", let us take a brief look at the literature related to health status in northern regions on a global scale. First, while social determinants of health are the major drivers in the creation of a healthy population, health care services and health care professionals also play a vital role in the building of health capacity in northern regions. The provision of health services in northern regions is significantly impacted by rurality and geographical isolation. Health care services available to residents in northern regions are lacking particularly for specialties such as obstetrics, gynecology, oncology, oral health care, and mental health services ${ }^{[4]}$. Women giving birth in the north may be attended by midwives or lay birth attendants, although in most cases women are forced to travel great distances to give birth as smaller communities often do not provide this care ${ }^{[5]}$. In northern Canada, pregnant mothers are most commonly sent south to tertiary care centres to give birth, although a maternity centre in Nunavut is available for eligible low risk women ${ }^{[6]}$. Similarly, the entire country of Greenland is serviced by only 16 Danish midwives, leaving more than 60 communities without local birthing services ${ }^{[5]}$. Due to long distances, preventative services such as oral health care are commonly not available throughout northern areas such as Alaska, Nunavut, and Russia ${ }^{[7]}$. In Northern Russia, only one oncologist services the entire region, which encompasses nine small hospitals and four clinics ${ }^{[8]}$. Mental health services are especially limited despite mental health issues being a growing concern in northern areas ${ }^{[9]}$. Hospitals are also sparse in these areas, leaving those in need of care travelling long distances. For example, Greenland remodeled its health care system in 2009 by reducing 18 health districts to four, with a referral hospital in Nuuk, the main city; any individuals requiring surgery or specialized services are transported to Nuuk, and more difficult cases are transferred to Denmark $^{[10]}$. The number of physicians per 100,000 Greenland inhabitants was 167 in 2009, almost half that of any other Nordic country ${ }^{[9]}$. The situation is similar in Russia, with only 340 physicians available for every 100,000 people, and only a third of that number available in rural areas of Russia ${ }^{[8]}$. 


\subsection{Health and health services in Northern Saskatchewan}

Not dissimilar to their global counterparts, the health and demographics of Northern Saskatchewan residents, and the health services available to them also mirror the global situation. Approximately $46 \%$ of the population live on First Nation reserves and more than $85 \%$ of the population identify themselves as Indigenous ${ }^{[11]}$. Indigenous peoples in Canada include First Nations, Inuit and Métis people ${ }^{[12]}$. This population is younger than the province as a whole, with approximately 33\% younger than 15 years, and only 5\% older than 65 years; consequently, the birth rate is almost double the provincial rate ${ }^{[3,11]}$. Education rates are low, with only $46 \%$ of those aged 25 to 29 years having completed high school compared to $80 \%$ in the province as a whole; unemployment is four times higher than the provincial rate ${ }^{[11]}$.

Lifestyle practices such as smoking are prevalent, with $40 \%$ (double the provincial rate) of those living off reserve being smokers ${ }^{[11]}$. The life expectancy in Northern Saskatchewan is five years shorter than the rest of the province; the most prevalent causes of death are injury and suicide, both of which are at higher rates than the rest of the province ${ }^{[11]}$. Obesity is common, with $65 \%$ of those living off reserve being overweight or obese, and this contributes to higher rates of diabetes in the north compared to the rest of the province ${ }^{[11]}$. The occurrence of lung cancer is also higher in Northern Saskatchewan, and infectious diseases such as chlamydia, tuberculosis, and hepatitis $\mathrm{C}$ are five, 90, and two times greater, respectively, in the north compared to the province and Canada as a whole ${ }^{[11]}$. The rate of HIV in the north is comparable to the provincial rate, but has been steadily increasing over time ${ }^{[11]}$.

Similar to other northern regions of the world, provision of health services in Northern Saskatchewan is challenging. This large land area has a small, widely dispersed population: approximately 36,000 people in greater than 70 communities ${ }^{[11]}$. However, only five communities have hospitals and resident doctors ${ }^{[13]}$. Distance is not the only issue affecting the delivery of health services. In 2001, northern health leaders created the Northern Health Strategy (NHS), bringing together 13 partner agencies to address common health issues in Northern Saskatchewan ${ }^{[14]}$. Governance of northern health services in Canada is a complex process, as on-reserve Indigenous population health services are funded by the federal government and managed either directly by the federal government or devolved to First Nations communities themselves. Services to off-reserve First Nations, Métis, and non-Indigenous populations are provided by provincial health services organizations. While northern health issues do not fall under a single jurisdiction, all health providers and northern residents face similar challenges, including duplication of some services and the absence of others ${ }^{[14]}$. The overarching objective of the NHS was therefore to work together across jurisdictional boundaries to improve the health status of all northern residents. By coordinating multi-jurisdictional decisions, the NHS aimed to provide northern residents with the health services they require in a cost-efficient and effective manner. Unfortunately, due to shifting provincial priorities and loss of federal funding, the NHS was abandoned in 2011.

\subsection{The state of health education in the North}

During this same period, northern health service organizations and post-secondary institutions educating health professions came together in the Northern Health Sector Training Sub-Committee (NHSTSC) of the Northern Labour Market Committee to develop a long-term educational strategy to address the human resources requirements as related to health in Northern Saskatchewan.

The Northern Labour Market Committee originated in 1983 as a mechanism by which agencies that funded education and training programs in Northern Saskatchewan could discuss labour market issues and ways in which they could collaborate to fund educational programming. Currently it consists of over 80 decision makers from education, funding, economic development, and Aboriginal organizations as well as industry sectors. The focus of the Committee is to identify labour market, and economic development issues, and to coordinate and support collaborative training to address these issues ${ }^{[15]}$.

The objective of the NHSTSC was to maximize opportunities for northerners to participate in health careers. Subcommittee members included northern, provincial, and First Nations health representatives, training institutions, tribal 
councils, and Métis organizations, as well as Saskatchewan Health and First Nations Inuit Health of Health Canada ${ }^{[13]}$.

A 2008 report commissioned by the NHSTSC demonstrated a significant and ongoing shortage of health personnel in Saskatchewan ${ }^{[13]}$. As of October 31, 2007, 10\% of all budgeted health positions were vacant. Annual turnover rate in the provincially funded northern system was $19 \%$ and in northern Health Canada organizations was $25 \%$. The report predicted that the northern health workforce would require 170 new hires per year over the ensuing five years to sustain health services ${ }^{[13]}$. Registered nurses represented the largest number of new hires required.

In addition to an overall lack of personnel, the report indicated a significant shortage of Indigenous workers. At the time of the report, the overall workforce in the north was made up of $62 \%$ Indigenous workers, significantly less than the Indigenous proportion (85\%) of the northern population. However, very few of the health professionals, including nurses, indicated Indigenous ancestry; rather, the demographics of health professionals in Northern Saskatchewan are similar to national values. While statistics on Indigenous registered nurses in Canada are limited, there are clearly very few ${ }^{\text {[16] }}$. Of the 252,000 nurses in Canada in 2003, an estimated 1000-1200 were of Indigenous ancestry ${ }^{\text {[17] }}$. A national task force assembled in 2002 and reassembled in 2007 found the overall number of Indigenous nursing students in Canada increased from 237 to 730 over that five year period ${ }^{[18,19]}$. However, the 2007 numbers represent only $1.27 \%$ of the total number of nursing students in Canada ${ }^{[20]}$. The number of Aboriginal nursing students would need to triple to accurately reflect the $3.8 \%$ of Canada's population that is Aboriginal ${ }^{[21]}$. Overall, the limited number of Indigenous nurses in Northern Saskatchewan mirrors national trends.

Moreover, the majority of health professionals, including nurses, in remote Northern Saskatchewan are itinerant, travelling from major centers for blocks of time to provide service. Evidence has shown that the itinerant model of delivering health care results in reactive, treatment-oriented, on-demand care rather than health promotion and prevention-based approaches ${ }^{[22,23]}$. Such approaches result in health services that are often not rooted in, or responsive to, community needs. The 2008 NHSTSC report concluded that northern health needs could not be met without a concerted effort to provide education and training at the community level; to be successful, communities and post-secondary institutions would need to work closely together ${ }^{[13]}$.

\subsection{The evolution of health professional education in Northern Canada}

The history of undergraduate health professional education in the north in Canada is limited, especially at the baccalaureate level. Those living in northern Canada have few options for pursuing health professional education. Options for residents include a practical nurse program through Yukon College ${ }^{[2]}$, and both bachelor and master of nursing programs as well as a primary nurse practitioner program through Aurora College, Northwest Territories ${ }^{[25]}$. Nunavut is by far the educational leader in northern Canada in terms of healthcare professions, offering programs such as practical nurse, bachelor of northern nursing, community health representative, community therapy assistant, home care worker, maternity care worker, mental health program, midwifery, and social services worker to its residents through Nunavut Arctic College ${ }^{[26,27]}$. In the Northern Saskatchewan context, anyone who wished to pursue a career as a registered nurse prior to 2003 had to move south to Saskatoon or Regina, both several hundred kilometers away. Since 2003, the University of Saskatchewan, College of Nursing has offered baccalaureate nursing education in Prince Albert, a community $140 \mathrm{~km}$ north of the main campus in Saskatoon. However, Prince Albert is over two hours away from the nearest population center in the north, and is not considered by northerners to be truly "north". While some northern students did move to Prince Albert, their numbers were few, and not all returned to their home communities on completion. For most potential northern students, moving to pursue education is simply not an option; northern and Indigenous people tend to have children at a young age, and many potential candidates for nursing education are tied to their home communities by the needs of their families and are not able to move to southern communities to pursue their education ${ }^{[28]}$. 


\section{Seizing the opportunity, engaging the possible}

At the same time that Saskatchewan's northern health service providers and post-secondary education institutions were coming together to explore new models to meet the health needs of Northern Saskatchewan residents, nursing education in the province was changing. In 2006, in correspondence with its current educational partners, the provincial regulatory province and the provincial government, the College of Nursing signaled its intent to develop a new nursing curriculum with a pre-professional year of arts and sciences classes and interprofessional opportunities for students with other health sciences colleges ${ }^{[29]}$. In 2008, the provincial government released a new Nursing Education Strategy for Saskatchewan ${ }^{\text {[30] }}$ which significantly increased the number of seats in the province and proposed that nursing education in Saskatchewan be provided on a distributed model—using teaching methods and technology that deliver education to students who are not physically present at the institution where the education originates. This would serve to increase the number of students educated outside of the major urban centers.

These changes at the college and provincial level provided an important opportunity for the University of Saskatchewan to consider offering nursing education programming in the north. Such an initiative required new models and approaches, and the College of Nursing recognized a unique opportunity to develop a northern nursing education program in collaboration with a number of partners in the community and in response to community needs. The University of Saskatchewan has a long-held tradition of linking its work with the communities it serves. In charting the strategic directions of the University in 2002, then President Peter McKinnon advocated that the University continue its storied role as an institution with a well-developed "sense of place" — a recognized connection with the people and communities of Saskatchewan ${ }^{[31]}$. Arising from this commitment to community engagement, the College of Nursing developed six principles on which to base program development (see Table 2).

Table 2. Principles of college of nursing program development ${ }^{[32]}$

\begin{tabular}{|c|c|}
\hline Principle & Definition \\
\hline Principle of Responsiveness and & College programs are developed to increase opportunity to recruit and retain highly \\
\hline Flexibility for Student Learning & qualified nurses in the Saskatchewan workforce. \\
\hline $\begin{array}{l}\text { Principle of Investing in Human/Social } \\
\text { Capital }\end{array}$ & $\begin{array}{l}\text { The College cultivates relationships with external resources to enhance program } \\
\text { delivery across the province. }\end{array}$ \\
\hline $\begin{array}{l}\text { Principle of Research Intensiveness for } \\
\text { both Undergraduate and Graduate Student } \\
\text { Learning }\end{array}$ & $\begin{array}{l}\text { Students at all levels will be exposed to research that will determine best practices } \\
\text { based on evidence. }\end{array}$ \\
\hline $\begin{array}{l}\text { Principle of a Knowledge Economy for } \\
\text { Saskatchewan }\end{array}$ & $\begin{array}{l}\text { College programs promote knowledge intensiveness of the Saskatchewan health care } \\
\text { system. }\end{array}$ \\
\hline $\begin{array}{l}\text { Principle of Mutual Understanding, } \\
\text { Recognition and Respect }\end{array}$ & $\begin{array}{l}\text { The College engages with knowledge leaders, both internal and external, to } \\
\text { acknowledge diversity of values and beliefs for health and well being. }\end{array}$ \\
\hline $\begin{array}{l}\text { Principle of Capacity Building at the } \\
\text { Community Level }\end{array}$ & $\begin{array}{l}\text { The College focuses on innovative projects that broaden health human resources and } \\
\text { are responsive to skills valued by employers. }\end{array}$ \\
\hline
\end{tabular}

In September 2012, the College of Nursing admitted 14 students to its new northern undergraduate nursing program, 11 of whom declared Indigenous ancestry. The program is based in two remote communities in Northern Saskatchewan: La Ronge, a largely First Nations community with a town and surrounding area of approximately 5,600 people, and Île-à-la-Crosse, a largely Métis community of 1,400 people. The College of Nursing was able to launch this program due to concerted efforts on the part of many different organizations and individuals. Some of the processes and approaches that led to the successful implementation of this program are chronicled below.

\subsection{Developing relationships and processes for success}

To achieve the goal of delivering a program relevant to the context of Northern Saskatchewan, the College chose an innovative framework that recognizes the connectedness among environment, social interaction, and symbolic meaning within a population. As an approach, Williams' concept of Therapeutic Landscapes (TL) offers a way to analyze the 
influence of the contextual factors of place on health and values and attitudes on well-being ${ }^{\text {[3, } 34]}$. TL helps to position nursing education as a way of "putting health into place" ${ }^{34]}$ that is culturally relevant and responsive to the social and economic changes within the north. The conceptual approach of TL, with its embedding of action in the local fabric of the community, informs the way in which the College interacts with the northern communities to plan and deliver its undergraduate programming. TL reasons that putting "health in place" is intentional, purposeful, and is reflective of the characteristics impacting the health of the people within a community or a particular geographical context ${ }^{[34]}$. This conceptual influence guides student interactions with the community in ways that are mutually beneficial. Students' stories of their experiences can contribute to expanding the concept of landscapes as influenced by meaning of place, understandings of how health and well-being are culturally defined, prior experiences of health, and health practice that are contextually symbolic ${ }^{[34]}$.

The decision to use a distributed learning model for undergraduate education, defined as separation of time and/or space in teaching and learning, extended the reach of the College of Nursing into communities where relationships were not well established, few clinical placements for student learning existed, and little was known about access to health services delivery. The prevalent model was, and continues to be, to remove patients from their communities and send them for service delivery in southern urban settings. This was the same approach used in education, which was not successful. Consistent with the TL framework, three key strategies were implemented: realignment of the College leadership structure to relate more closely to the health regions, ongoing engagement with the intellectual community of nurses in the local area, and tri-partite agreements that are mutually beneficial to the College's three essential partners: the communities themselves, the health region decision makers, and local post-secondary educational institutions.

A key change was a redesign of the leadership structure within the College of Nursing, moving away from the traditional model of alignment in relation to internal operations to better reflect the provincial mandate of the program. Three out of scope Associate Dean positions were developed and aligned with the provincial distribution of health regions. The goal was to connect education directly to practice and thereby support mutually beneficial arrangements for recruitment and retention as part of the health human resource planning for the region. This restructuring allowed for strengthening of relationships and increasing connectedness in the social environment between the College, northern communities, and post-secondary institutions, an essential component when creating TL. The implementation of the Associate Dean position dedicated to relationships in the north also served as a powerful symbolic gesture demonstrating the College's commitment to meaningful community engagement.

The Associate Dean who assumed the northern portfolio was given the unique responsibility to establish new directions for nursing education while contributing to a "northern health employment development and training program" as deemed necessary by the NHSTSC report ${ }^{[13]}$. The delivery of the College program in largely Indigenous communities to students who were also predominantly Indigenous provided a unique opportunity to link the curriculum to issues of importance to Indigenous and northern communities in both the local and global circumpolar context. The focus on global Indigenous health issues in the portion of the program offered in the north enhances the curriculum at other southern College undergraduate program sites, as well as other programs at the graduate level; the overall intent is to increase interest in research and scholarly work in northern health for faculty and students across all sites.

In keeping with the TL framework focus on social interaction, broad consultation was held with the Chief Executive Officers (CEOs) of the northern health regions, local nursing leaders and staff nurses, and staff at regional outpost primary care clinics to determine the benefit and preparedness of a community to accept students. Resident nursing alumni were consulted for guidance on bringing the program to the northern region. College nursing alumni were important resources with respect to learning and understanding the culture and values placed on health within the communities.

Another key to the success of the College's distributed learning strategy was its partnership with Northlands College, a regional college serving the north of the province, to deliver its nursing program in the north. Since 1973, Saskatchewan 
has provided post-secondary education outside major urban centers through seven regional colleges, with over 50 campuses. Northlands provided the infrastructure and student supports for the nursing program, as well as many years of experience in Indigenous and northern student success. The College of Nursing provided support through supplying the curriculum and instruction, using its tenured faculty. A community meeting hosted by the Saskatchewan Academic Health Sciences Network in March, 2011, was arranged to begin to engage and build relationships between physicians, nurses, educators in both the elementary and secondary schools as well as regional college systems, and Indigenous leaders from across two northern health regions who would be influenced by the implementation of the nursing program. This collaboration was central to the success of the tri-partite agreement.

\subsection{Learn where you live}

Building on the College's sense of place, the distributed learning model was designed to provide access to students who would not otherwise be able to attend the University. The College's "learn where you live" approach dedicated 15 seats to the north for northern residents. Admission to the BSN program was consistent with the entry requirements for all applicants, independent of campus locations. A northern resident was defined using the long-standing geographical marker referred to as the NAD. Students who did not fit this criterion were not admitted to the northern sites. The implementation of the program was predicated on an agreement between the health region, the regional college that served the community, and the College of Nursing. This tri-partite agreement resulted in Northlands College delivering classes using distributed methods and infrastructure such as web-based and video-conferencing techniques. The health region provided clinical learning opportunities, and, on occasion, registered nurses from their staff to assist with the teaching and evaluation of student skill development. The College of Nursing relied on its relationship with these organizations as well as its community and alumni relationships to engage local nurses with nursing students in both formal learning and social situations. The involvement of local nurses was intended to promote linkages between nurses and students that would prove valuable during student clinical experiences and ultimately support the heath human resource planning needs of the region. Such relationships were also hoped to spark professional synergy, thus stimulating the engagement of local nurses in local leadership and professional opportunities. Given that TL refers to places associated with health and healing, the work of practicing nurses in local hospitals, clinics and community settings contributes to the meanings associated with health related landscapes. Registered nurses have the opportunity to shape landscapes through actions that demonstrate an understanding of local determinants impacting how health and healthcare occurs in their local community or place. Sharing this knowledge with learners who will become the future northern workforce is invaluable to build intellectual and socially relevant capacity for health care delivery.

The College maintains the position that no community would be considered for clinical placements as a means to an end. Nursing student placement in a clinical setting was founded on a mutually beneficial agreement such that students became immersed in learning the values ascribed to health within the social and economic context of the community. In an applied context, TL suggests that the concept of therapeutic community focuses attention on the connectedness of social relationships, meaningful work and the quality of the environment to promote healing ${ }^{[35]}$. Using the constructs within a TL (connectedness among environment, social interaction, and symbolic meaning within a population), the College is able to identify communities that are well positioned to support health and well-being as well as those challenged by poor health and health behaviours. The impact of environmental factors, such as housing, transportation, and water quality, provide evidence of the interplay between environmental and social determinants shaping the landscape of community that affects health and well-being. Using TL to study health in place, nursing students can serve these communities by understanding the relationship between sense of place and putting health in place to create supportive environments for sustainable health services ${ }^{[34]}$.

\subsection{The key to success: It is all about relationships}

During the planning and implementation of this program, College leaders recognized the necessity of formal partnership agreements and the vital support at senior levels of partner organizations; however, overall success was dependent on a variety of individuals at a number of levels. Especially important was the support at the front line interface between 
students and their environment. For example, the College administrator went to the Mayor of Île-à-la-Crosse for assistance with housing for the students. He worked with other organizations in the village, but also used one-on-one personal networks to seek out suitable solutions for students and their families. Implementation of College technological connections for videoconferencing and other technology-based pedagogies would not have been possible without the tireless work of the maintenance staff at the hospital in Île-à-la-Crosse where the College classroom was located. When student uniforms failed to arrive in their entirety, the housekeeping staff at the La Ronge Health Center quickly found scrub pants for the students to wear for their first clinical rotation. In Île-à-la-Crosse, front line staff in both the hospital and the high school offered to provide printing services until issues encountered with the classroom printer could be rectified. In short, formal partnerships were an essential part of the success of the program, but the relationships "on the ground" were what ultimately made things work.

\subsection{Taking the college to the North}

The College of Nursing's approach to distributed learning was predicated on taking the College to the north. The documented need for health human resource planning and health service delivery provided an important impetus to College of Nursing involvement. The desire on the part of the College to expand its reach and increase its understandings of Indigenous ways of knowing and Indigenous views of science, health, and learning provided the opportunity to create innovative approaches for education and practice, thereby enabling professional and community-based synergies in a model that can be tested locally and compared globally.

Students were taught by expert researchers and experienced professors who could link their teaching to current evidence and best practice. These professors, who communicated with the students through technological links, worked remotely alongside local nurses who were based in the classroom. This model built capacity in local communities, as local nurses became versed in the best practice literature while assisting experts to apply these approaches to the local context. The local nurses learned new pedagogical approaches and increased their confidence and skills in teaching, a skill that benefits them in preceptoring students and working with colleagues in the clinical setting. These nurses were provided opportunities to understand and engage in the research and scholarly work of faculty members, and were exposed to new ways of thinking, doing, and being.

A Northern Saskatchewan Health Indicators Report was completed in 2004 by the Population Health Unit associated with the three Northern Saskatchewan health regions, and subsequently updated in 2011. While health challenges remain significant, the 2011 report showed improvements to some of the health and social conditions in the north, including an increasing number of high school graduates, increasing life expectancy, decreasing infant death rate and death from congenital anomalies, and decreasing incidence of certain diseases ${ }^{[11]}$. The recent increase in positive health and social outcomes is attributed to greater access to health promotion and preventative services in Northern Saskatchewan ${ }^{[11]}$. Contributing to engaging communities in health promotion and prevention is a major focus for both faculty and students in undergraduate nursing programs. Future reports may demonstrate a further positive influence of the local nursing program on health outcomes.

Bringing together individuals experienced in distributed learning methods with community members will help to position the University of Saskatchewan, College of Nursing as a world leader in changing how health education, practice, and research are realized in rural and remote communities. Notably, the success of the delivery model is based on building and sustaining relationships.

\section{Conclusion}

To address a critical shortage of registered nurses in Northern Saskatchewan, dynamic multi-sectoral collaboration involving communities, industry, healthcare, and academia emerged to create an environment that could affect sustainable outcomes in education, health, and economic development. Global intelligence and culturally sensitive leadership are 
central to the College of Nursing's integrated plan to deliver nursing education. The distributed learning approach captures the political will for social change currently transcending collegial, institutional, provincial, and national borders. The outcome of the College's northern program is the application of new knowledge that can be directly applied to improving access to health education and service delivery of Indigenous people within Northern Saskatchewan.

The success of this nursing program cannot be measured solely by traditional metrics such as the number of registrants and corresponding graduates. The College's tri-partite agreement has led to commitments from health regions and communities to building human capital in the north. The College of Nursing's willingness to embrace innovative, studentand community-centered approaches to nursing education is being done with the intention of impacting the community on a larger scale than nursing and health care. Rather, the hope is to produce and foster leadership in the community through its students and through the College's relationships within the community and build capacity for transformative change within the communities involved, within the students, but more broadly, within the College of Nursing itself.

So how will the College know if it has succeeded in achieving such lofty goals? The College will be challenged to develop new evaluation approaches that capture the community development and transformational aspects of this initiative. TL provided a framework for demonstrating the interconnectedness of individuals, communities, service delivery and education to seek new approaches for social problems that impact quality of life in the north. Capitalizing on the "shared intelligence" ${ }^{[36]}$ within the northern landscape, situated nursing to become context relevant thus allowing for new learning strategies aimed at solving long standing health issues. To capture the interconnection measures of social innovation ${ }^{[36-38]}$ provides both social and financial metrics. Social innovation believes collaboration across sectors is needed to find the best ideas, given limited resources, for outcomes that will solve complex societal problems. The strength of involvement will lead to greater participation in decisions that ultimately affect issues that impact their lives, in this case, nursing education for improved health. Social innovation maps the landscape of how shared intelligence has evolved thus identifying strengths and/or gaps as thematic networks of stakeholders. The outcome is knowledge of the enablers and facilitators within the TL in addition to the traditional focus on knowing the needs of the consumer. Concepts of TL enable impact measurement in addition to impact performance.

Future reports of health outcomes in the north may also begin to demonstrate the positive impact of bringing health education to the north, and beginning to build local nursing capacity. But perhaps program success can best be illustrated in the interim by the story of the Île-à-la-Crosse students' first day of clinical experience in the local long-term care center. The students, outfitted in their new uniforms complete with the College of Nursing cresting and nursing student name tags, were greeted when they came to the unit by members of the senior administration of the health region, who came to acknowledge them and communicate the region's pride in their achievements. Throughout the day, community members, staff members from other parts of the health center, and family members of the facility clients came to the unit to take their pictures, to wish them well, and to share in the students' pride as they set out in their new role. The residents for whom they cared beamed as they told others that these students were from their communities, and that they were going to be nurses who cared for their own people. For the people of this community, this was a momentous day, marking a new beginning. They were excited for these students, for the health of their communities, and for the role modeling that these students would provide to community youth. The community response demonstrates the effectiveness of using TL as a foundation for creating an environment that can support health education in northern communities.

\section{References}

[1] Hamelin L. Canadian Nordicity: It’s Your North, Too. Montreal: Harvest House; 1979.

[2] Government of Saskatchewan. The Northern Municipalities Act, 2010 [Internet]. 2010. Available from: www.qp.gov.sk.ca/documents/English/Statutes/Statutes/N5-2.pdf

[3] Statistics Canada. Census Report, Division No. 18, Saskatchewan (Code 4718) and Saskatchewan (Code 47) [Internet]. 2012. Available from: 
http://www12.statcan.ca/census-recensement/2011/dp-pd/prof/details/page.cfm?Lang=E\&Geo1=CD\&Code1=4718\&Geo2=PR \&Code2=47\&Data=Count \&SearchText=Division No. 18\&SearchType=Begins\&SearchPR=01\&B1=All\&GeoLevel=PR\&Geo Code $=4718 \&$ TABID $=1$

[4] Elliott B, Larson J. Adolescents in mid-sized and rural communities: Foregone care, perceived barriers, and risk factors. J Adolesc Heal. 2004; 35: 303-9. PMid:15450544 http://dx.doi.org/10.1016/j.jadohealth.2003.09.015

[5] Bjerregaard P, Olesen I. Giving birth in Greenland: Secular change in acceptance of hospital deliveries. Int J Circumpolar Health [Internet]. 2010 Dec; 69(5): 480-5. Available from: http://www.ncbi.nlm.nih.gov/pubmed/21073826 PMid:21073826 http://dx.doi.org/10.3402/ijch.v69i5.17680

[6] Douglas VK. The Rankin Inlet birthing centre: Community midwifery in the Inuit context. Int J Circumpolar Health [Internet]. 2011 Apr; 70(2): 178-85. Available from: http://www.ncbi.nlm.nih.gov/pubmed/21481300 PMid:21481300 http://dx.doi.org/10.3402/ijch.v70i2.17803

[7] Gorbatova M a, Gorbatova LN, Grjibovski AM. Dental caries experience among 15-year-old adolescents in north-west Russia. Int J Circumpolar Health [Internet]. 2011 Jun; 70(3): 232-5. Available from: http://www.ncbi.nlm.nih.gov/pubmed/21703127 PMid:21703127

[8] Vaktskjold A, Ungurjanu T, Klestsjinov N. Cancer incidence in the Nenetskij Avtonomnyj Okrug, Arctic Russia. Int J Circumpolar Health. 2008; 67(5): 433-44. PMid:19186764 http://dx.doi.org/10.3402/ijch.v67i5.18359

[9] Marcussen J. Health Statistics in the Nordic Countries [Internet]. 2011. Available from: http://nomesco-eng.nom-nos.dk/default.asp?side=189

[10] Niclasen B, Mulvad G. Health care and health care delivery in Greenland. Int J Circumpolar Health [Internet]. 2010 Dec; 69(5): 437-47. Available from: http://www.ncbi.nlm.nih.gov/pubmed/21118636 PMid:21118636 http://dx.doi.org/10.3402/ijch.v69i5.17691

[11] Irvine J, Quinn B, Stockdale D. Northern Saskatchewan health indicators report 2011 summary [Internet]. 2011. Available from: http://www.populationhealthunit.ca/media/Northern Saskatchewan Health Indicator Report 2011 Summary.pdf

[12] University of British Columbia. University of British Columbia: First Nations studies program. Terminology [Internet]. 2009. Available from: http://indigenousfoundations.arts.ubc.ca/home/identity/terminology.html

[13] Thompson L. A report on a northern health human resources data collection [Internet]. 2008. Available from: http://www.nhhr.ca/uploads/NHHR_NEEDS_ASSESSMENT.pdf

[14] Government of Saskatchewan. Northern Health Strategy [Internet]. 2013. Available from: http://www.health.gov.sk.ca/northern-health-strategy

[15] Keewatin Career Development Corporation. Northern Labour Market Committee History [Internet]. 2013. Available from: http://career.kcdc.ca/index.php/labour-market/10-labour-market/29

[16] Aboriginal Nurses Association of Canada [ANAC]. Fact Sheet [Internet]. 2013. Available from: http://www.anac.on.ca/Documents/Nursing Fact Sheet Final.pdf

[17] National Aboriginal Health Organization. Analysis of Aboriginal Health Careers Education and Training Opportunties [Internet]. 2003. Available from: http://www.naho.ca/documents/naho/english/pdf/analysis_health_careers.pdf

[18] Gregory D. Against the odds: Aboriginal nursing [Internet]. 2002. Available from: https://www.uleth.ca/dspace/handle/10133/615

[19] Gregory D. Against the odds: An update on Aboriginal nursing in Canada [Internet]. 2007. Available from: https://www.uleth.ca/dspace/bitstream/handle/10133/522/Against_the_Odds_2007_Update_April_16.pdf?sequence=4

[20] Canadian Nurses Association, Canadian Association of Schools of Nursing. Nursing education in Canada: Statistics 2007-2008 [Internet]. Ottawa, ON; 2009. Available from: http://www.cna-aiic.ca/ /media/cna/page-content/pdf-en/education_statistics_report_2007_2008_e.pdf

[21] Human Resources and Skills Development Canada. Canadians in context: Aboriginal population [Internet]. 2008. Available from: http://www4.hrsdc.gc.ca/.3ndic.1t.4r@-eng.jsp?iid=36

[22] Schroth RJ. The state of dental health in the north. Int J Circumpolar Health [Internet]. 2006 Apr;65(2):98-100. Available from: http://www.ncbi.nlm.nih.gov/pubmed/16711462 PMid:16711462 http://dx.doi.org/10.3402/ijch.v65i2.18096

[23] Browne G, Birch S, Thabane L. Better care: An analysis of nursing and healthcare system outcomes [Internet]. 2012. Available from: http://www2.cnaiic.ca/CNA/documents/pdf/publications/nec/BetterCare_Browne-EN-Web-SHORT.pdf

[24] Yukon College. Practical nurse [Internet]. 2012. Available from: http://www.yukoncollege.yk.ca/programs/view/prnr

[25] Aurora College. Alphabetical Program Listing [Internet]. 2012. Available from: http://www.auroracollege.nt.ca/_live/pages/wpPages/ProgramsAtoZ.aspx

[26] James S, Brien BO, Bourret K, Kango N, Gafvels K. Meeting the needs of Nunavut families : A community-based midwifery education program. Rural Remote Health. 2010; 10. 
[27] Nunavut Arctic College. Health and Wellness Programs [Internet]. 2012. Available from: http://www.arcticcollege.ca/en/health-programs

[28] Young O, Einarsson N. Arctic human development report [Internet]. 2004 p. 1-235. Available from: http://www.svs.is/ahdr/ahdr chapters/english version/chapters pdf.htm

[29] University of Saskatchewan: College of Nursing. Achievement Record [Internet]. 2012. Available from: http://www.usask.ca/nursing/docs/CoNAchievementRecord.pdf

[30] Ross L. Commitment to Care: Nurse Recruitment and Retension in Saskatchewan [Internet]. 2009. Available from: http://www.usask.ca/nursing/docs/report_commitment_to_care.pdf

[31] University of Saskatchewan. University of Saskatchewan Strategic Directions: Renewing the Dream [Internet]. 2002. Available from: http://www.usask.ca/ipa/documents/renewing_the_dream.pdf

[32] University of Saskatchewan: College of Nursing. Self-evaluation report for new program. Saskatoon, Saskatchewan; 2011.

[33] Kearns R, Gesler W. Putting Health into Place. In: Williams A, editor. Therapeutic Landscapes. Burlington, VT: Ashgate Publishing Company; 2007. p. 113.

[34] Braubach M. Preventive Application of the Therapeutic Landscapes Concept in Urban Residential Settings: A Quantitative Application. In: Williams A, editor. Therapeutic Landscapes. Burlington, VT: Ashgate Publishing Company; 2007; 111-32.

[35] Hoey B. Therapeutic uses of place in the intentional space of purposive community. In: Williams A, editor. Therapeutic Landscapes. Burlington, VT: Ashgate Publishing Company; 2007; 297-314.

[36] O’Sullivan C, Mulgan G. Financing social impact: Funding social innovation in Europe, mapping the way forward [Internet]. 2012. Available from: www.socialinnovationeurope.eu

[37] Harji K, Jackson E. Accelerating impact: Achievements, challenges and what's next in building the impact investment industry. New York; 2012.

[38] Canadian Task Force on Social Finance. Harnessing the power of social finance: Canadians respond to the national call for concepts for social finance. Toronto Social Innovation Generation; 2013. 